\title{
STUDI LITERATUR : HUBUNGAN ASUPAN SERAT TERHADAPKADAR GLUKOSA DARAH POSTPRANDIAL
}

\author{
Brilianti Viapita $^{1}$, Raihanah Suzan ${ }^{2}$, Erny Kusdiyah ${ }^{2}$ \\ 1)Mahasiswa Program Studi Kedokteran, Fakultas Kedokteran dan Ilmu Kesehatan Universitas \\ Jambi2)Dosen Progam Studi Kedokteran, Fakultas Kedokteran dan IImu Kesehatan Universitas \\ Jambi \\ Email: briliantiviapita@rocketmail.com ${ }^{1}$
}

\begin{abstract}
Background: According to the World Health Organization (WHO), the number of people with Diabetes Mellitus (DM) worldwide in 2000 was 177 million people and increased to 194 million people in 2003. Increased blood glucose levels, especially postprandial blood glucose levels play an important role in the pathogenesis of DM. Diet or nutritional therapyplays an important role in postprandial glucose control, one of them is the consumption of high-fiber diets.

Objective: To determine the relationship between between fiber intake and postprandial blood glucose levels. Methods: This study used a literature review approach with a research method scoping review, using ten literatures sourced from search results through the search engine Google Scholar, PubMed, Science Direct, and DOAJ according to the inclusion criteria determined by the researcher.
\end{abstract}

Results: There are 8 literatures show a significant relationship between fiber intake and postprandial blood glucose levels ( $p$ value $<0.05$ ). Other 2 literatures show no significant relationship between high fiber intake and postprandial blood glucose levels.

Conclusion: Adequate fiber intake has a significant relationship in the reduction of postprandial blood glucose levels in subjects with normal glucose tolerance, glucose intolerance, pre-diabetes, and type 2 diabetes mellitus with the agerange of subjects $18-85$ years ( $p$ value $<0.05$ )

Keywords: Fiber intake, Postprandial Blood Glucose

\begin{abstract}
ABSTRAK
Latar Belakang: Menurut World Health Organization (WHO), jumlah penderita Diabetes Mellitus (DM) di seluruh duniapada tahun 2000 adalah 177 juta orang dan meningkat menjadi 194 juta orang pada tahun 2003. Peningkatan kadar glukosa darah terutama kadar glukosa darah postprandial berperan penting dalam patogenesis terjadinya DM. Pengaturan pola makan atau terapi nutrisi berperan penting dalam kontrol glukosa postprandial yakni, salah satunya dengan konsumsi makanan tinggi serat.
\end{abstract}

Tujuan Penelitian: Untuk mengetahui hubungan asupan serat terhadap kadar glukosa darah postprandial.

Metode: Penelitian ini menggunakan pendekatan studi literatur dengan metode penelitian scoping review yang menggunakan sepuluh literatur yang bersumber dari hasil penelusuran melalui search engine Google Scholar, PubMed, Science Direct, dan DOAJ sesuai dengan kriteria inklusi yang sudah ditetapkan peneliti.

Hasil : Sebanyak 8 literatur menunjukan adanya hubungan signifikan antara asupan serat dan kadar glukosa darah postprandial ( $p$ value $<0.05$ ). Sebanyak 2 literatur menunjukan tidak ada hubungan yang signifikan antara tingginya asupan serat terhadap kadar glukosa darah postprandial. 
Kesimpulan : Asupan Serat yang cukup memiliki hubungan yang signifikan terhadap penurunan kadar glukosa darahpostprandial baik pada subyek dengan toleransi glukosa normal, intoleransi glukosa, pre-diabetes, dan diabetes melitus tipe 2 dengan rentang usia subyek 18-85 tahun ( $p$ value $<0.05$ )

Kata Kunci : Asupan Serat, Glukosa Darah Postprandial

\section{PENDAHULUAN}

Diabetes mellitus (DM)merupakan suatu penyakit degeneratif yang prevalensinya semakin meningkat dari tahun ketahun. ${ }^{1}$ Peningkatan kadar glukosa darah termasuk kadar glukosa darah postprandial berperan penting dalam patogenesis terjadinya DM. Tingginya kadar glukosa darah postprandial telah lama dikaitkan dengan peningkatan tekananan oksidatif, penyebab terjadinya penyakit kardiovaskular dan penyebab berbagai mortalitas lainnya. Oleh karena itu dibutuhkan adanya usaha untukpenanganan kontrol glukosa darah. ${ }^{2,3,4}$

Pengaturan pola makan atau terapinutrisi berperan penting dalam kontrol glukosa postprandial yakni, dengan konsumsi sumber karbohidrat kompleks dengan indeks glikemik rendah atau beban glikemik makanan rendah dan konsumsi makanan tinggi serat. ${ }^{3,5}$ Banyak penelitian telah membuktikan bahwa asupan serat yang tinggi berpengaruh terhadap penurunan kadarglukosa darah postprandial baik pada subjek non-diabetes, prediabetik dan diabetes, dan menurunkan faktor risiko kondisi kronis termasuk intoleransi glukosa, hiperinsulinemia, dan hiperlipidemia postprandial. $^{4}$

Hal tersebut dikarenakan serat terutama serat larut air yang masuk bersama makanan akan menyerap banyak cairan di dalam lambung dan membentuk makanan menjadi lebih kental. Makanan yang lebih kental akan memperlambat proses pencernaan sehingga proses penyerapan nutrisiseperti glukosa akan terjadi secaralambat. Penyerapan glukosa yang lambat akan menyebabkan kadar glukosa darah menurun. ${ }^{5}$ Namun, rata- rata konsumsi serat pangan penduduk Indonesia adalah 10,5 gram perhari. Angka ini menunjukkan bahwa penduduk Indonesia baru memenuhi kebutuhan seratnya sekitar sepertiga dari kebutuhan ideal sebesar 30 gram setiap hari. ${ }^{6}$

Pada penelitian yang dilakukan olehKapoor $\mathrm{MP}^{4}$ didapatkan bahwa pemberian asupan Partially Hydrolysed Guar Gum (PHGG) sebanyak 6 gr/hari terbukti efektif dalam mengontrol kadar glukos darah postprandial, hiperlipidemia, metabolism hormone incretin baik pada orang sehat maupun orang dengan intoleransi glukosa.Begitu pula pada penelitian yang dilakukan oleh $\mathrm{Kim} \mathrm{HK}^{7}$ tentangpengaruh asupan snack terhadap kadar glukosa darh postprandial, dari penelitian tersebut dapat diketahui bahwa mengonsumsi snack yang mengandung serat tinggi merupakan cara efektif untuk mengontrol kadar glukosa postprandial dan efek kontrol glikemik tersebut berlangsung hingga sarapan pagi keesokan harinya. Akan tetapi, pada penelitian yang dilakukan oleh Amankwaah $\mathrm{AF}^{8}$ didapatkan hasil bahwa asupan tinggi serat setiap sarapan tidak mempengaruhi kadar glukosa darah postprandial pada orang dewasa yang overweight. 
Berdasarkan uraian diatas diketahuibahwa peningkatan kadar glukosa darah postprandial memberikandampak yang buruk namun tingkat asupan serat di masyarakat masih rendah padahal berbagai penelitian yang telah membuktikan bahwa asupanserat tinggi mampu mengontrol kadar glukosa postprandial. Oleh karena itu, peneliti tertarik untuk meneliti tentang "Studi Literatur: Hubungan Asupan Serat Terhadap Kadar Glukosa Darah Postprandial".

\section{METODE PENELITIAN}

Desain penelitian yang digunakan adalah desain studi scoping review. yaitu suatu metode yang dilakukan melalui penelusuran dengan membaca berbagai sumber baik buku, jurnal, dan terbitan-terbitanlain yang berkaitan dengan topik penelitian, untuk menjawab permasalahan yang ada yang dilakukan secara sistematis tanpa ada keharusan melakukan critical appraisal dansintesis sistematis. Dalam melakukan penelitian ini peneliti melakukan pencarian jurnal penelitian yang dipublikasikan di internet menggunakan search engine seperti search engine Google Scholar, PubMed, dan Science Direct. Penilaian terhadap jurnal dilihat dari abstrak apakah berdasarkan tujuan penelitian.

Penelusuran literatur menggunakan kata kunci: "fiber intake and postprandial glucose". Penelusuran literaturdilakukan sejak bulan September 2020 hingga bulan Oktober 2020. Didapatkan 10 temuan literatur yang dispesifikan dalam 5 tahun terakhir, mengenai pemilihan bahasa tidak dilakukan karena semua jurnal yang ditemukan telah menggunakan bahasa inggris.

\section{HASIL}

Tabel 1. Hasil Kajian Studi Literatur

\begin{tabular}{|c|c|c|c|c|c|}
\hline $\mathrm{NO}$ & Judul (Penulis) & Sampel & Serat & Waktu & $\begin{array}{l}\text { Efek pada glukosa } \\
\text { darah postprandial }\end{array}$ \\
\hline 1. & $\begin{array}{l}\text { Soluble dietary fibre partially } \\
\text { hydrolysed guar gum markedly } \\
\text { impacts on postprandial } \\
\text { hyperglycaemia, } \\
\text { hyperlipidaemia and incretins } \\
\text { metabolic hormones over time } \\
\text { in healthy and glucose } \\
\text { intolerant subjects (Kapoor MP } \\
\text { dkk) }\end{array}$ & $\begin{array}{l}12 \text { orang dewasa tanpa } \\
\text { penyakit gastrointestinal dan } \\
\text { penyakit metabolik dengan } \\
\text { rentang usia } 43 \text { - } 49 \text { tahun, } \\
\text { yang terdiri dari } 6 \text { orang } \\
\text { dengan toleransi glukosa } \\
\text { normal, } 4 \text { orang dengan } \\
\text { intoleransi glukosa, dan } 2 \\
\text { orang dengan } \\
\text { prediabetes melitus }\end{array}$ & $\begin{array}{l}6 \text { gram partially } \\
\text { hydrolysed guar gum } \\
\text { selama paruh pertama } \\
\text { setiap kali makan ( } 3 \\
\text { kali sehari) }\end{array}$ & 12 bulan & $\begin{array}{l}\downarrow \text { signifikan } \\
p<0,005\end{array}$ \\
\hline 2. & $\begin{array}{l}\text { Effect of the Intake of a Snack } \\
\text { Containing Dietary Fiber on } \\
\text { Postprandial Glucose Levels } \\
\text { (Kim HK dkk). }\end{array}$ & $\begin{array}{l}9 \text { orang dewasa } \\
\text { tua ( } 70-85 \text { tahun) sehat yang } \\
\text { terdiri dari } 4 \text { orang laki- laki } \\
\text { dan } 5 \text { orang perempuan } 22 \\
\text { orang berusia } \\
50-80 \text { tahun yang tidak } \\
\text { mengidap penyakit kronis }\end{array}$ & $\begin{array}{l}\text { DF-biskuit yang } \\
\text { mengandung } 9,2 \text { gram } \\
\text { serat pada minggu } \\
\text { kedua }\end{array}$ & 2 minggu & $\begin{array}{l}\downarrow \text { signifikan } \\
\mathrm{p}<0,005\end{array}$ \\
\hline 3. & $\begin{array}{l}\text { Effect of macronutrients and } \\
\text { fiber on postprandial glycemic } \\
\text { responses and meal glycemic } \\
\text { index and glycemic load value } \\
\text { determinations (Meng H } \\
\text { dkk) }\end{array}$ & $\begin{array}{l}9 \text { orang dewasa } \\
\text { tua ( } 70-85 \text { tahun) sehat yang } \\
\text { terdiri dari } 4 \text { orang laki- laki } \\
\text { dan } 5 \text { orang perempuan } 22 \\
\text { orang berusia } \\
50-80 \text { tahun yang tidak } \\
\text { mengidap penyakit kronis }\end{array}$ & $\begin{array}{l}\text { Roti tawar ditambah } \\
\text { sereal oat yang } \\
\text { mengandung } 4,8 \text { atau } \\
9,6 \text { gram }\end{array}$ & 12 minggu & $\begin{array}{l}\text { Tidak ada } \\
\text { penurunan } \\
\text { signifikan } \mathrm{p}>0,05\end{array}$ \\
\hline 4. & $\begin{array}{l}\text { Effects of Higher Dietary } \\
\text { Protein and Fiber Intakes at }\end{array}$ & $\begin{array}{l}20 \text { orang overweight berusia } \\
21-45 \text { tahun }\end{array}$ & $\begin{array}{l}2 \text { gram psyllium husk } \\
\text { powder /hari pada }\end{array}$ & 15 minggu & Tidak ada \\
\hline
\end{tabular}




\begin{tabular}{|c|c|c|c|c|c|}
\hline & $\begin{array}{l}\text { Breakfast on Postprandial } \\
\text { Glucose, Insulin, and 24-h } \\
\text { Interstitial Glucose in } \\
\text { Overweight Adults } \\
\text { (Amankwaah AF dkk) }\end{array}$ & & $\begin{array}{l}\text { minggu uji tipe } \\
\text { sarapan dengan } \\
\text { asupan protein } \\
\text { normal, ataupun } \\
\text { protein tinggi dengan } \\
\text { asupan serat normal } 8 \\
\text { gram psyllium husk } \\
\text { powder /hari } \\
\text { pada minggu uji tipe } \\
\text { sarapan dengan } \\
\text { asupan tinggi protein, } \\
\text { ataupun normal } \\
\text { protein dengan } \\
\text { asupan tinggi } \\
\text { serat }\end{array}$ & & $\begin{array}{l}\text { penurunan } \\
\text { signifikan } p>0,05\end{array}$ \\
\hline 5. & $\begin{array}{l}\text { Effect of consuming oat bran } \\
\text { mixed in water before a meal } \\
\text { on glycemic responses in } \\
\text { healthy humans (Steinert RE } \\
\text { dkk) }\end{array}$ & $\begin{array}{l}10 \text { orang dengan berat badan } \\
\text { normal, overweight, dan } \\
\text { obesitas yang terdiri dari } 5 \\
\text { orang perempuan dan } 5 \text { orang } \\
\text { laki-laki dengan rentang } \\
\text { usia } 22-65 \text { tahun }\end{array}$ & $\begin{array}{l}0,9 \text { gram, } 2,6 \\
\text { gram, } 5,3 \text { gram oat } \beta \text { - } \\
\text { glukan }\end{array}$ & 4 minggu & $\begin{array}{l}\downarrow \text { signifikan } \\
\mathrm{p}<0,005\end{array}$ \\
\hline 6. & $\begin{array}{l}\text { A double-blind randomised } \\
\text { controlled trial testing the } \\
\text { effect of abarley product } \\
\text { containingvarying } \\
\text { amounts and types of fibre } \\
\text { on the postprandial } \\
\text { glucose response of } \\
\text { healthy } \\
\text { volunteers (Ames } N d k k \text { ) }\end{array}$ & $\begin{array}{l}7 \text { laki-laki dan } 5 \text { perempuan } \\
\text { berusia19-35 tahun tanpa } \\
\text { penyakit kronis }\end{array}$ & $\begin{array}{l}8 \text { dosis : 4,2-14gram } \\
\text { barley }\end{array}$ & 6 minggu & $\begin{array}{l}\downarrow \text { signifikan } \\
\mathrm{p}<0,005\end{array}$ \\
\hline 7. & $\begin{array}{l}\text { Consumption of the } \\
\text { soluble dietary fibre } \\
\text { complex polyglycopleX } \\
\text { reduces glycaemia and } \\
\text { increases satiety of a } \\
\text { standard meal } \\
\text { postprandially (Solah VA } \\
\text { dkk) }\end{array}$ & $\begin{array}{l}14 \text { orang dewasa sehat yang } \\
\text { terdiri dari } 2 \text { laki-laki dan } 12 \\
\text { perempuan dengan rentang } \\
\text { usia } 19-32 \text { tahun }\end{array}$ & $\begin{array}{c}\text { Granula : } 5 \\
\text { gram } \\
\text { Kapsul : 4,5gram }\end{array}$ & 12 minggu & $\begin{array}{l}\downarrow \text { signifikan } \\
\mathrm{p}<0,005\end{array}$ \\
\hline 8. & $\begin{array}{l}\text { Postprandial glucose- } \\
\text { lowering effect of premeal } \\
\text { consumption of protein- } \\
\text { enriched, dietary fiber- } \\
\text { fortified bar in individuals } \\
\text { with type } 2 \text { diabetes } \\
\text { mellitus or normal glucose } \\
\text { tolerance (Bae JH dkk) }\end{array}$ & $\begin{array}{l}\quad 30 \text { orang dengan } \\
\text { rentang usia } 18-80 \text { tahun yang } \\
\text { terdiri dari } 15 \text { orang dengan } \\
\text { diabetes melitus tipe } 2 \text { dan } 15 \\
\text { orang dengan toleransi } \\
\text { glukosa normal }\end{array}$ & 12,7 gram bar & 1 minggu & $\begin{array}{l}\downarrow \text { signifikan } \\
\mathrm{p}<0,005\end{array}$ \\
\hline 9. & $\begin{array}{l}\text { Effects of brown } \\
\text { seaweeds on postprandial } \\
\text { glucose, insulin and } \\
\text { appetite in humans } \\
\text { (Zaharudin N) }\end{array}$ & $\begin{array}{l}20 \text { orang sehat yang terdiri } \\
\text { dari } 9 \text { laki-laki dan } 11 \\
\text { perempuan denganrentan } \\
\text { usia } 20-50 \text { tahun }\end{array}$ & $\begin{array}{l}5 \text { gram Laminaria } \\
\text { digitata yang } \\
\text { mengandung } \\
1.8 \text { gram serat } 5 \text { gram } \\
\text { Undaria } \\
\text { Pinnatifida yang } \\
\text { mengandung } \\
1.7 \text { gram serat } \\
\end{array}$ & 3 minggu & $\begin{array}{l}\downarrow \text { signifikan } \\
\mathrm{p}<0,005\end{array}$ \\
\hline 10. & $\begin{array}{l}\text { Effects of dietary fiber on } \\
\text { postprandial glucose in } \\
\text { healthy adults (Yesmin F } \\
\text { dkk) }\end{array}$ & $\begin{array}{l}50 \text { orang dewasa baik } \\
\text { sehat laki-lakimaupun } \\
\text { perempuan tanpa penyakit } \\
\text { metabolik }\end{array}$ & $\begin{array}{l}\text { Isphagula } 10,5 \text { gram } \\
\text { yang ditambahkan } \\
\text { pada larutan } 50 \mathrm{gram} \\
\text { glukosa dalam } \\
250 \mathrm{ml} \text { air }\end{array}$ & 11 bulan & $\begin{array}{l}\downarrow \text { signifikan } \\
\mathrm{p}<0,001\end{array}$ \\
\hline
\end{tabular}




\section{PEMBAHASAN}

\section{Karkteristik Subyek Penelitian Pada Studi Literatur}

Berdasarkan hasil telaah 10 literatur yang telah dikumpulkan, diketahui bahwa pada penelitian tersebut subyek yang digunakan diteliti memiliki usia dengan rentang 18-85 tahun dengan subyek terbanyak pada usia $\geq 45$ tahun. Usia merupakan salah satu faktor yang mempengaruhi kadar glukosa darah terutama glukosa postprandial. Telah banyak penelitian yang menyebutkan bahwa kadarglukosa darah postprandial lebih tinggi pada orang usia tua dibandingan dengan orang usia muda. Hal tersebut disebabkan karena semakin bertambah usia, perubahan fisik danpenurunan fungsi tubuh akan mempengaruhi konsumsi dan penyerapan zat gizi. Pada penelitian yang dilakukan oleh Basu $\mathrm{R}$, dkk ${ }^{9}$ dijelaskan bahwa perbedaan kadar glukosa postprandial yang lebih tinggi pada orang usiatua dibandingan dengan orang usia muda disebabkan oleh tingkat pembuangan glukosa yang lebih rendah, dimana hal itu dipengaruhi oleh adanya retensi insulin, gangguan sekresi insulin dan peningkatan ekstraksi insulin dihepar.

Berdasarkan hasil review dari 10 literatur, didapatkan sebanyak 5 literatur tidak merincikan jumlah jenis kelamin subyek. Sementara 5 literatur sisanya merincikan jenis kelamin subyek dan dari total data jumlah jenis kelamin subyek pada 5 literatur tersebut didapatkan hasil bahwa sebagian besar subyek penelitian sebanyak 58,4\% (38 orang) adalah perempuan, sedangkan subyek berjenis kelamin laki-laki sebanyak 41,5\% (27orang). Beberapa teori menjelaskan bahwa jenis kelamin ikut berpengaruh terhadap kadar glukosa darah postprandial. Hal tersebut sejalan dengan penelitian yang dilakukan

Sicree, dkk ${ }^{10}$ di Australia dimana didapatkan hasil bahwa kadar glukosa darah postprandial pada perempuan lebih tinggi daripada laki-laki. Adanya perbedaan tersebut berhubungandengan adanya perbedaan tinggi badan antara laki-laki dan perempuan. Dimana pada umumnya orang yang lebih tinggi (kebanyakan laki-laki) memiliki massa otot yang lebih kecil, yang mana otot merupakan jaringan utama yang terlibat dalam penyimpanan glukosa. Selain itu adanya perbedaan kadar hormon progesteron dan estrogen yang kadarnya lebih rendah pada laki-laki juga ikut berpengaruh. Peningkatan kadar progesteron ketika wanita sedang menstruasi dikatakan dapat menyebabkan resistensi insulin temporer, sehingga menyebabkan kadar glukosa darah lebihtinggi dari normal. ${ }^{11}$

Pada 10 literatur yang telah ditelaah, didapatkan sebanyak 6 literatur meneliti subyek yang sehat dengan IMT normal, tanpa menderita penyakit komorbid. Terdapat 1 literatur meneliti subyek dengan intoleransi glukosa dan pre-diabetes melitus tipe 2 . Sebanyak 1 literatur meneliti subyek dengan diabetes melitus tipe 2 . Serta sebanyak 2 literatur meneliti pada subyek yang overweight dan obesitas. IMT dan penyakit penyerta merupakan faktor yang juga ikut berperan dalam mempengaruhi kadar glukosa darah postprandial. Pada penelitian yang dilakukan tingginya kadar glukosa darah postprandial pada orang overweight dan obesitas dikarenakan orang dengan berat badan 
berlebih cenderung menyimpan kelebihan energi dalam bentuk jaringan lemak yang mana hal tersebut berpotensi menyebabkan retensi insulin yang berpengaruh terhadap kadar glukosa darah. ${ }^{13}$ Sementara pada orangdengan penyakit penyerta khususnya diabetes melitus tipe 2 yang merupakan suatupenyakit dimana insulin tidak bisa menjalankan tugasnya secara optimal sehingga mengakibatkan tingginya kadar glukosa darah postprandial.

\section{Jumlah Intervensi Asupan Serat dan Kadar Glukosa Darah Postprandial Subyek Studi Literatur}

Dari telaah 10 literatur yang dilakukan, intervensi asupan serat pada penelitian tersebut bervariasi pada rentang 0,4-14 gram/hari dengan jangka waktu pemberian kurang dari 1-12 bulan. Pada penelitian yang dilakukan Kapoor MP, dkk ${ }^{11}$ pemberian intervensi asupan serat sebanyak 6 gram partially hydrolysed guar gum selama 12 bulan didapatkan kadar glukosa darah postprandial $134,33 \pm 8,92 \mathrm{mg} / \mathrm{dL}$ pada subyek dengan toleransi glukosa normal, $182 \pm 6,15 \mathrm{mg} / \mathrm{dL}$ pada subyek dengan intoleransi glukosa, serta $232 \pm 14 \mathrm{mg} / \mathrm{dL}$ pada subyek dengan prediabetes melitus. Pada penelitian yang dilakukan Kim HK, dkk ${ }^{7}$ pemberian biskui oleh Putri $A B$, dkk didapatkan hasil bahwa semakin tinggi IMT maka semakin tinggi pula kadar glukosa darah postprandial. Hal ini sesuai dengan teori yang menjelaskan bahwa yang mengandung 0,4 gram serat pada minggu pertama didapatkan kadar glukosa darah postprandial maksimum subyek 134,5 \pm 2,3 $\mathrm{mg} / \mathrm{dL}$ sementara pada pemberian DFbiskuit yang mengandung 9,2 gram serat pada minggu kedua didapatkan kadar glukosa darah postprandial subyek 130,1 $\pm 3,7 \mathrm{mg} / \mathrm{dL}$, hal tersebut menunjukan bahwa rerata penurunan glukosa postprandial lebih tinggi pada minggu kedua saat pemberian DF- biskuit walaupun perbedaan yang ditunjukan tidak begitu signifikan. Pada penelitian yang dilakukan Meng $\mathrm{H}$, dkk ${ }^{14}$ pemberian Roti tawar ditambah sereal oat yang mengandung serat sebanyak 4,8 selama 12 minggu didapatkan kadar glukosa darah 2 jam postprandial subyek 7,1 \pm $1.1 \mathrm{mmol} / \mathrm{L}$ sementara pada pemberian roti tawar yang ditambah sereal oat dengan kandungan serat sebanyak 9,6 gram didapatkan kadar glukosa darah postprandial subyek 7,0 $\pm 1,4 \mathrm{mmol} / \mathrm{L}$ yang mana hal tersebut menunjukan tidak adanya penurunan yang signifikan terhadap kadar glukosa postprandial.

Sementara pada penelitian yang dilakukan oleh Steinert RE, dkk ${ }^{15}$ yang juga memberikan oat $\beta$-glukan sebanyak 0,9 gram, 2,6 gram, 5,3 gram selama 4 minggu menunjukan penurunan yang signifikan terhadap kadar glukosa postprandial pada semua dosis. Pada penelitian yang dilakukan oleh Amankwaah $\mathrm{AF}, \mathrm{dkk}^{8}$ pemberian 2 gram psyllium husk dan 8 gram psyllium husk selama 15 minggu tidak menunjukan adanya pengaruh signifikan terhadap kadar glukosa postprandial. Pada penelitian yang dilakukan oleh Ames, dkk ${ }^{16}$ pemberian 8 dosis : 4,2-14 gram barley selama 6 minggu menunjukan semakin tinggi dosis barley yang diberikan maka semakin menunjukan penurunan yang signifikan terhadap kadar glukosa postprandial. Pada penelitian yang dilakukan 
oleh Solah VA, dkk8 pemberian polyglycopleX® sebanyak 5 gram untuk sediaan granula dan 4,5 gram untuk sediaan kapsul didapatkan hasil bahwa sediaan granula terbukti efektif dalam penurunan kadar glukosa postprandial. Pada penelitian yang dilakukan oleh Hyun J, dkk8 pemberian 12,7 gram bar pada orang dengan diabetes melitus tipe 2 dan orang dengan toleransi glukosa normal menunjukan penurunan yang signifikan terhadap kadar glukosa postprandial pada kedua subyek penelitian. Pada penelitian yang dilakukan oleh Zaharuddin N, dkk17 pemberian 5 gram Laminaria digitata yang mengandung 1.8 gram serat dan 5 gram Undaria Pinnatifida yang mengandung 1.7 gram serat menunjukan pengaruh signifikan terhadap penurunan kadar glukosa postprandial. Pada penelitian yang dilakukan oleh Yesmin F, dkk17 pemberian Isphagula 10,5 gram yang ditambahkan pada larutan 50 gram glukosa dalam $250 \mathrm{ml}$ air selama 11 bulan menunjukan penurunan yang signifikan terhadap kadar glukosa postprandial.

\section{Hubungan Asupan Serat Terhadap Kadar Glukosa Darah Postprandial}

Berdasarkan hasil review yang dilakukan dari 10 literatur, terdapat 8 literatur menunjukan adanya hubungan signifikan antara asupan serat dan kadar glukosa darah postprandial ( $p$ value $<0.05$ ). Hal ini sesuai dengan teori yang menyebutkan bahwa saat di dalam usus besar, serat yang masih utuh dapat difermentasi oleh bakteri di usus besar sehingga terbentuklah SCFA (Short- Chain Fatty Acid) yang merupakan asam lemak rantai pendek. Pembentukan SCFA ini menginduksi sekresi hormon GLP-1 (Glucagon Like Peptide-1), GIP (Gastric Inhibitory Polypeptide), dan PYY (Peptide YY) yang akan meningkatkan sensivitas insulin dan akhirnya menyebabkan penurunan kadar glukosa dalam darah.5,18

Sebanyak 2 literatur menunjukan tidak ada hubungan yang signifikan antara tingginya asupan serat terhadap penurunan kadar glukosa darah postprandial. Penelitian yang dilakukan oleh Meng $\mathrm{H}$, dkk14 pada tahun 2017 di Amerika ditemukan bahwa tidak ada pengaruh yang signifikan antara tingginya asupan serat terhadap kadar glukosa darah postprandial subyek ( $p$ value 0.35 ). Namun pada penelitian tersebut dijelaskan bahwa sereal oat yang digunakan pada penelitian mengandung $\beta$-glukan yang merupakan salah satu jenis serat. Selama proses pembuatan makanan, makanan yang mengandung serat dapat berbeda dalam banyak hal karena gangguan fisik dan paparan panas. Sehingga ada kemungkinan $\beta$-glukan terdegradasi selama proses penyiapan makanan. Hal ini didukung oleh teori yang menjelaskan bahwa $\beta$-glukan harus memiliki berat molekul serta harus berada pada viskositas yang optimal.untuk bisa memberikan efek terapi.19 dengan variabel-variabel yang terkait dengan tingginya glukosa darah postprandial.

Pada penelitian yang dilakukan oleh Amankwaah AF, dkk11 pada tahun 2017 juga menunjukan bahwa tingginya asupan serat saat sarapan tidak memberikan pengaruh signifikan terhadap kontrol kadar glukosa postprandial ( $p$ value 0.795), tetapi dari 
penelitian tersebut ditemukan bahwa tingginya asupan serat saat sarapan memberikan efek yang signifikan terhadap kontrol respon insulin postprandial. Namun pada penelitian tersebut dijelaskan bahwa asupan makan malam subyek tidak dikontrol. Hal tersebut sesuai dengan teori yang menjelaskan bahwa efek sisa dari makan malam dapat mempengaruhi profil glukosa pada pagi berikutnya.

\section{KESIMPULAN}

Berdasarkan hasil dari literatur review pada 10 literatur tentang hubungan asupan serat terhadap kadar glukosa darah postprandial didapatkan kesimpulan bahwa Terdapat hubungan yang signifikan antara pemberian asupan serat terhadap kadar glukosa darah postprandial baik pada subyek dengan kondisi toleransi glukosa normal, intoleransi glukosa, prediabetes, dan juga diabetes melitus tipe 2 dengan rentang usia subyek 18-85 tahun $(p<0.05)$.

\section{SARAN}

Rekomendasi dari peneliti yaitu perlu dilakukan penelitian lebih lanjut mengenai permasalahan yang lebih mendalam berkaitan Untuk Institusi Kesehatan, peneliti menyarankan bahwa perlu mengadakan penyuluhan baik di tingkat sekolah, perguruan tinggi maupun masyarakat terkait pentingnya konsumsi serat harian yang cukup.

\section{REFERENSI}

1. Rahayu HT, Hudha AM, Umah US. Perbandingan Self-Awareness Pola Konsumsi Makanan danOlahraga dengan Riwayat Keluarga Memiliki dan Tidak Memiliki Diabetes Melitus Tipe II Pada Mahasiswa PSIK UMM. 6:15-26.

2. Isnaini N, Ratnasari R. Faktor risiko mempengaruhi kejadian Diabetes mellitus tipe dua. J Kebidanandan Keperawatan Aisyiyah. 2018;14(1):59-68.

3. Bae JH, Kim LK, Min SH, Ahn CH, Cho YM. Postprandial glucose-lowering effect of premeal consumption of protein-enriched, dietary fiber-fortified bar in individuals with type 2 diabetes mellitus ornormal glucose tolerance. J Diabetes Investig. 2018;9(5):1110-8.

4. Kapoor MP, Ishihara N, Okubo T. Soluble dietary fibre partially hydrolysed guar gum markedly impactson postprandial hyperglycaemia, hyperlipidaemia and incretins metabolic hormones over time in healthy and glucose intolerant subjects. J Funct Foods [Internet]. 2016;24:207-20. Available from: http://dx.doi.org/10.1016/j.jff.2016.04.008

5. Soviana E, Maenasari D. Asupan Serat, Beban Glikemik Dan Kadar Glukosa Darah Pada PasienDiabetes Melitus Tipe 2. J Kesehat. 2019;12(1):19-29.

6. Rahmah A, rezal F, rasma R. Perilaku Konsumsi Serat Pada Mahasiswa Angkatan 2013 FakultasKesehatan Masyarakat Universitas Halu Oleo Tahun 2017. J Ilm Mhs Kesehat Masy Unsyiah. 2017;2(6):198088.

7. Kim HK, Nanba T, Ozaki M, Chijiki H, Takahashi M, Fukazawa M, et al. Effect of the intake of a snackcontaining dietary fiber on postprandial glucose levels. Foods. 2020;9(10):1-11.

8. Amankwaah AF, Drew Saye R, Wright AJ, Chen N, McCrory MA, Campbell WW. Effects of higherdietary protein and fiber intakes at breakfast on postprandial glucose, insulin, and 24-h interstitial glucose in 
overweight adults. Nutrients. 2017;9(4).

9. Basu R, Man CD, Campioni M, Basu A, Klee G, Toffolo G, et al. Effects of age and sex on postprandialglucose metabolism differences in glucose turnover, insulin secretion, insulin action, and hepatic insulin extraction. Diabetes. 2006;55(7):2001-14.

10. Sicree RA, Zimmet PZ, Dunstan DW, Cameron AJ, Welborn TA, Shaw JE. Differences in height explain gender differences in the response to the oral glucose tolerance test - The AusDiab study. Diabet Med. 2008;25(3):296-302.

11. Wulandari D, Kurnianingsih W. Pengaruh Usia, Stres, dan Diet Tinggi Karbohidrat Terhadap KadarGlukosa Darah. J IIm rekam medis dan Inform Kesehat. 2018;8(1):16-25.

12. Putri AB, Anita A. Obesitas Sentral terhadap Kadar Gula Darah Postprandial pada Pegawai Laki-LakiDewasa di Lingkungan Kerja. J Kesehat. 2019;10(3):445.

13. Guyton AC, Hall JE. Buku Ajar Fisiologi Kedokteran. 12th ed. Jakarta: EGC; 2014.

14. Meng H, Matthan NR, Ausman LM, Lichtenstein AH. Effect of macronutrients and fiber on postprandial glycemic responses and meal glycemic index and glycemic load value determinations 1 - 3. 2017;(C).

15. teinert RE, Raederstorff D, Wolever TMS. Effect of consuming oat bran mixed in water before a meal on glycemic responses in healthy humans-A pilot study. Nutrients. 2016;8(9).

16. Association AD. Postprandial Blood Glucose. 2001;24(4):775-558

17. Yesmin F, Ali M, Sardar M, Munna M, Baksh S. Effects of dietary fiber on postprandial glucose in healthy adults. Mediscope. 2018;6(1):25-9.

18. Kusharto CM. Serat Makanan Dan Perannya Bagi Kesehatan. J Gizi dan Pangan. 2007;1(2):45.

19. Lazaridou A, Biliaderis CG. Molecular aspects of cereal $\beta$-glucan functionality: Physical properties, technological applications and physiological effects. J Cereal Sci. 2007;46(2):101- 